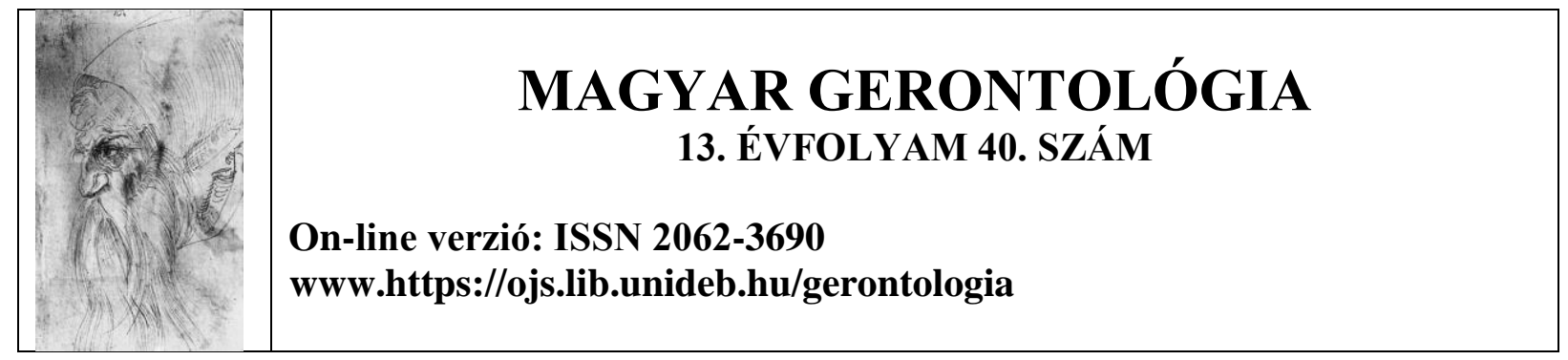

\title{
MOLEKULÁRIS GERONTOLÓGIA NAPJAINKBAN
}

\section{Pályiné dr. Krekk Zsuzsanna}

Debreceni Egyetem Egészségügyi Kar

Kulcsszavak: molekuláris gerontológia, öregedéselméletek, idegrendszer öregedése, vér-agy gát öregedése, Alzheimer-kór

\begin{abstract}
Absztrakt
Az öregedés komplex, molekuláris szintü folyamatainak megismerése és megértése napjainkban alapvető fontosságú. A molekuláris szintű mechanizmusok egyrészt értelmezik a klasszikus gerontológia élettani jelenségeit, másrészt prevenciós és terápiás lehetőségek alapját is képezhetik. Jelen irodalmi adatokon alapuló összefoglaló a molekuláris gerontológia néhány alapfogalmának összegzését követően a tudományterület legújabb eredményei közül az idegrendszer öregedésével kapcsolatos új eredmények közül kíván néhányat bemutatni.
\end{abstract}

Keywords: molecular gerontology, aging theories, nervous system aging, blood-brain barrier aging, Alzheimer's disease

\begin{abstract}
Recognizing and nderstanding the complex processes of aging at the molecular level is essential today. The mechanisms at the molecular level of aging interpret classical gerontological knowledge, on the other hand, they can form the basis of prevention possibilities. Following
\end{abstract}


the summation of some basic concepts of molecular gerontology, a summary based on this literary data aims to present some of the latest results in the field of neurosciential aging.

\section{Molekuláris gerontológia}

$\mathrm{Az}$ átlagéletkor folyamatos emelkedése globális és hazai viszonylatban egyaránt közismert (Gavrilov 2015), egyre inkább indokolttá válik az őszülő évszázad elnevezés. A statisztikai adatok az mutatják, hogy a 60 évesek és a 60 évnél idősebbek demográfiai részesedése $20 \%$ és $30 \%$ közé esik a fejlettebb társadalmakban és arányuk folyamatosan emelkedik (e-cím 1.) Ez az arány a magyarországi demográfiai adatokhoz hasonló tendenciájú. A KSH interaktív korfája jól reprezentálja a hazai idősödő társadalom életkori jellemzőit és modellezi a következő évtizedek várható demográfiai változásait. (1. ábra) (e -cím 2).

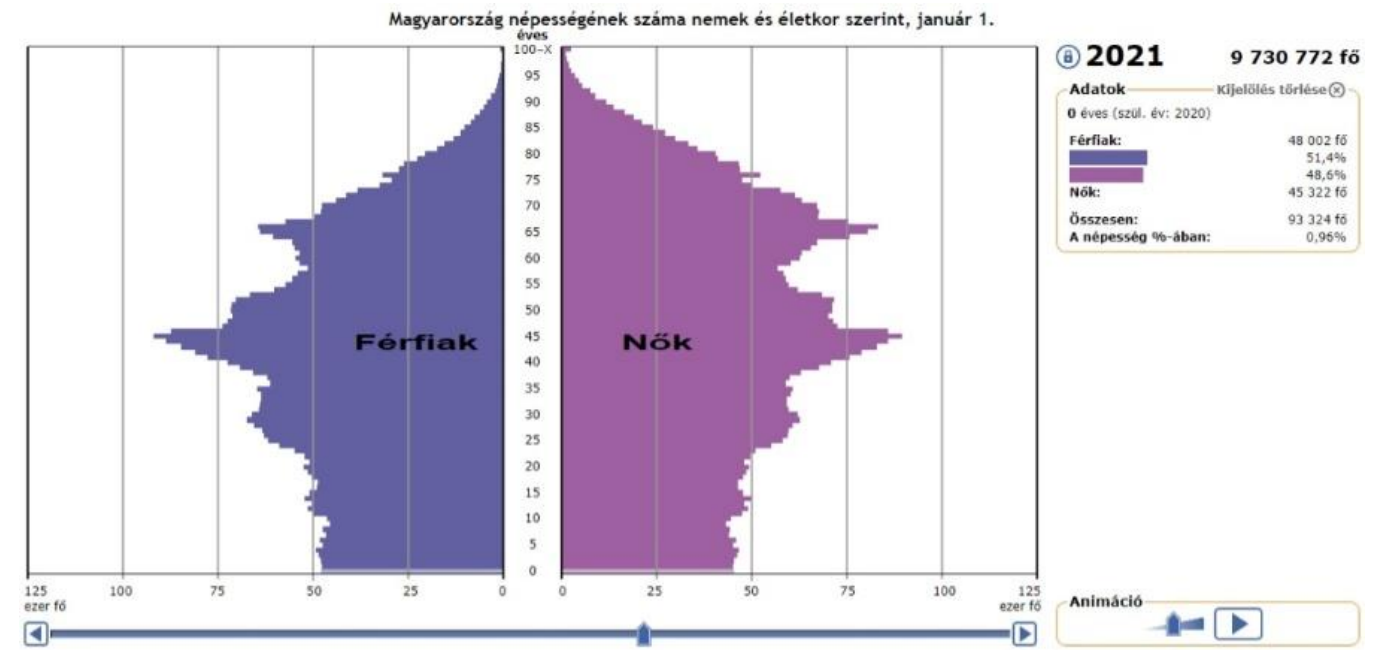

1. ábra. Magyarország népességének száma nemek és életkor szerint interaktív korfán ábrázolva (Forrás: KSH 2021.)

Az öregedési folyamatok kutatásának három nagy klasszikus területét különítjük el (Semsei 2011). A legismertebb a társadalomgerontológia, amely a társadalmi vonatkozásokat vizsgálja. Az idősödéssel összefüggő társadalmi jelenségekhez szorosan kapcsolódó érzelmi, értelmi és egyéb pszichológiai változásokat kutatja a pszichogerontológia. A harmadik kutatási terület a biogerontológia, amely az öregedési folyamatok biológiai vonatkozásait elemzi.

A gerontológiai kutatások mindhárom fö területét befolyásolja a megbetegedési gyakoriság időskori emelkedése. Közismert, hogy az életkor előrehaladtával a 
megbetegedések gyakorisága az életkorral arányosan növekszik. A statisztikai adatok alapján az esetszámok azt mutatják, hogy ez a köztudatban jelen lévő arányosság a betegségek megléte és az életkor nagysága között 60 és 80 éves kor között valósul meg leginkább. Meglepő módon az életkor további elörehaladásával a megbetegedések összesített aránya nem nő, sőt 80 éves kor után több kórkép esetén is csökkenő tendenciát mutat. (2. ábra) (Kvell 2011.)

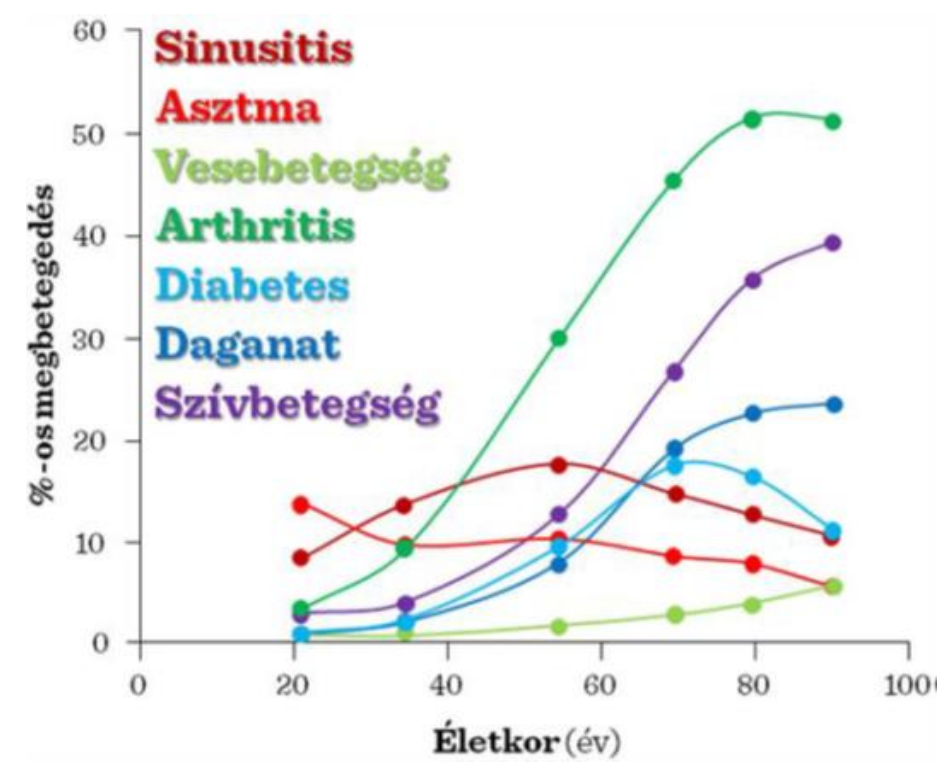

2. ábra: Megbetegedési gyakoriság az életkor függvényében. (Forrás: Kvell 2011.)

A jelenség magyarázata jelenleg nem ismert, de a folyamatok molekuláris szintű elemzése esetlegesen magyarázatot adhat ezekre a megfigyelésekre.

A biogerontológia kutatási területe rendkívül összetett (Suresh 2018), ezen belül került megfogalmazásra az öregedési elméletek egyre bővülő köre, amit a 3. ábra próbál a jelenlegi ismereteink alapján összefoglalni. (Kvell 2011.) 


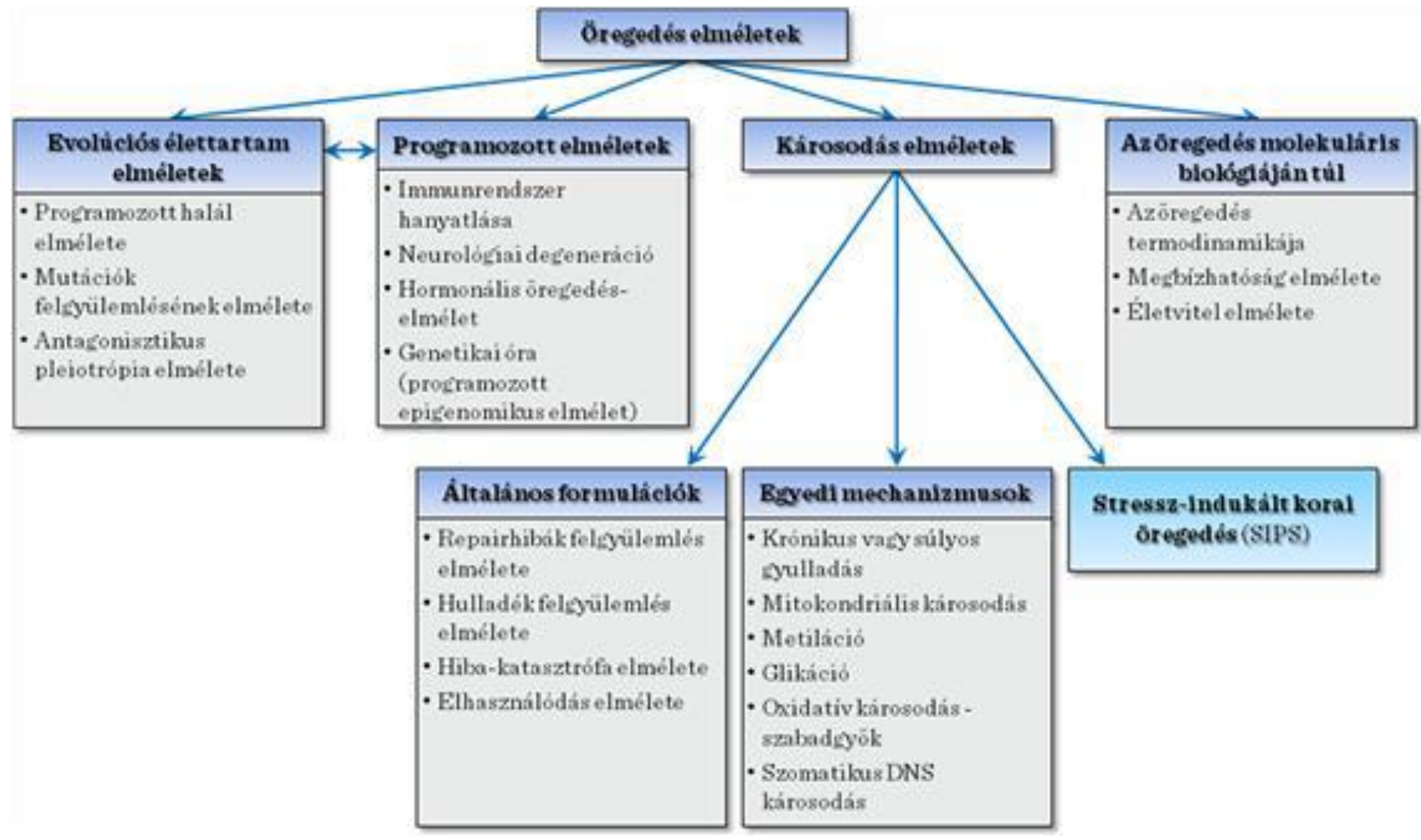

3. ábra: Föbb öregedési elméletek összefoglaló táblázata. (Forrás: Kvell 2011.)

Az ábra jól szemlélteti, hogy az öregedés komplex élettani folyamatában ma már egyre több összetevő molekuláris háttere vált ismertté. Ugyanakkor az ismert folyamatok száma egyre bővül. A kutatási eredmények azt mutatják, hogy molekuláris szinten minden emlős faj (rendszertanilag a Homo sapiens is) hasonló öregedési folyamatokat mutat. Habár az öregedési folyamat hátterében exponenciálisan növekvő számban írnak le molekuláris folyamatokat, az eredmények azt mutatják, hogy a javitási mechanizmusok (repair pathways) az egyik legjelentősebb élettartamot növelő mechanizmus csoport. A károsodást javító folyamatok fontosságát hangsúlyozó elképzelést alátámasztják a 3. ábrán bemutatott öregedési elméletek, amelyek közül a legnagyobb arányban éppen az említett károsodás öregedési elméletek vannak jelen a legnagyobb arányban.

Egyetlen gént ugyan nem tudtak azonosítani a javítási folyamatok kapcsán, de egyre több gént tudnak kapcsolni ehhez a folyamathoz, melyeket csoportnéven élettartam növelö géneknek (longevity assurance genes: LAG) neveznek (Rattan 2007). Ezek a gének szabályozzák a legismertebb öregedést lassító folyamatokat, mint például a DNS hibáit javító mechanizmusok (Park 2011), a sejtek transzlációs folyamatainak stabilitását biztosító hatásokat (Kirwood 1984) és a károsodott fehérjék lebontási hatékonyságának szabályozását (Scmith 2013). Az utóbbi folyamat kapcsán érdemes megemlíteni, hogy a hibás aminosav peptidláncba való 
beépülésének elfogadható mértéke kb. 5/10.000 aminosav. Szintén a LAG gének aktivitása révén valósul meg a stresszre adott válasz fokozása (Kapahi 1999) és a szabadgyökök, valamint az oxidáció okozta károsodás elleni védekezési kapacitás emelése (Jones 2015). Értelemszerüen ezeknek a géneknek a hibája az élettartam rövidüléséhez vezet. A humán mutációs ráta (ami a génhibák egyik indikátora) jelenleg ismert mértéke nagyságrendileg $10^{7-11}$ bázispáronként 1 mutáció.

Az öregedési folyamatok kapcsán szintén a legismertebb mechanizmusok közé tartozik a telomér rövidülés hatása (Broccoli 1995). Telomérnek nevezzük a kromoszómák végének repetitív DNS szekvenciákat tartalmazó régióját, funkciója a kromoszóma végének védelme a károsodásoktól az osztódás során. Müködése révén gátolja a gének degradációját a kromoszóma végeinél. Az öregedés folyamatában a telomér hossza is változik, ugyanakkor az is lehetséges, hogy a rövidülés nem oka, hanem következménye az öregedésnek.

Az öregedés mértékét befolyásoló mechanizmusok okozhatnak krónikus vagy súlyos gyulladást, mitokondriális károsodást (Slagboom1990), metilációt, ROS-mediált oxidatív károsodást és szomatikus DNS károsodást mutációkon keresztül

Jelenlegi ismereteink szerint nincs egyetlen öregedést leíró univerzális elmélet, hanem az öregedést egy komplex folyamatként szükséges értelmeznünk.

\section{Az idegrendszer öregedési folyamata}

Az élettani folyamatok így az öregedés szabályozásának központja az idegrendszer. Az idegrendszer ellátja szabályozási feladatát ebben a folyamatban miközben önmaga is öregszik. Számos az idősödéshez jellegzetesen társuló kórkép (Alzheimer kór, Parkinson-kór) is az idegrendszert érinti. A legfrissebb molekuláris gerontológiai eredmények közül többet is az idegrendszer öregedésével kapcsolatos kutatások eredményeként publikáltak, ami nem meglepő, hiszen a fenti kórképek súlyozott és emelkedő arányban vannak jelen az idősödő társadalmakban.

A központi és a perifériás idegrendszer is funkcionális hanyatlást mutat az öregedési folyamat során. A redukált funkciókat rendszerszerüen összegezve a perifériás idegrendszer károsodását az autonom, a motoros és a perifériás szenzoros funkciók egyéntől függő mértékü romlása mutatja. Míg (csak néhányat kiemelve) a csökkent térbeli tájékozódó képesség, a memóriavesztés (fiziológiás szinten), a gyengült poszturális reflexek és a károsodott motoros koordináció a központi idegrendszeri folyamatok idősödéssel járó csökkent müködését jelzik. 
A következőkben az idegrendszer öregedési folyamatához köthető legjellegzetesebb korképek rövid összefoglalására kerül sor.

A gerontológiai kutatásokban központi szerepet játszik az agyi keringési folyamatok (cerebral blood flow, CBF) elemzése, mivel ez a rendszer jelentős eltérést mutat a szervezet egyéb részeinek keringésétől. Már önmagában CBF autoregulácója is sokkal nagyobb mértékü a test többi részénél, mivel 60 és 140/160 Hgmm artériás középnyomási tartományban is képes fenntartatni a CBF állandóságát (Kvell 2011).

Az ischémia az agy egyik legnagyobb rizikófaktora, mely szintén a kóros agyi keringési folyamatokhoz tartozik. Az ischémia során romló vagy megszünő vérellátás nagyon gyors agyi funkcióvesztéshez vezet, aminek az egyik oka, hogy az agyban nincsenek energiaraktárak. A véráramlás 1-2 másodpercnyi megszünése eszméletvesztést, 3-5 perces leállás pedig irreverzibilis kéregkárosodást okoz. Érdekes megfigyelés, hogy az érzékenység mértéke nem szisztémás, hanem régiónként jelentős eltérések lehetnek, például az agytörzs 25-30 perces ischemiát is tolerálhat.

A CBF korfüggő csökkenését emberben és állatokban egyaránt diagnosztizálták, a csökkenés főként limbikus rendszert és az asszociációs kéreg régiókat érinti. A folyamat hátterében az áll, hogy prekapilláris arteriolák és kapillárisok sürüsége csökken, sőt ez a csökkenés akár a 40\%-t is elérheti. A CBF csökkenése miatti fiziológiás kockázatot növeli, hogy az agyi erek merevsége miatt fokozott rizikót jelent intrakraniális vérzésre fejtrauma vagy más megterhelés esetén.

A legelterjedtebb időseket érintő vaszkuláris eredetü idegrendszeri zavar a stroke. Az esetek többsége (80\%) ischemiás eredetü (tranziens ischemiás attack /=TIA/, ami 5 perc-től 24 óra alatt reverzibilis, vagy permanens, ill. progresszív formák), a maradék 20\% szubarachnoideális, vagy intracerebrális vérzéses stroke (Kvell 2011).

Az idős kor gyakoribb neurológiai kórképei közé tartozik az Alzheimer kór. Az Alzheimer kór egy progrediáló, idősebb életkorhoz kötődő ismeretlen eredetű kognitív funkcióvesztés, amely magatartási zavarokkal is jár (Kvell 2011, Semsei 2011). Az eseteknek csak a 20\%-a vezethető vissza genetikai okokra. A kór kialakulása során a neuronok, szinapszisok vesztése megy végbe, amely egyes agykérgi és szubkortikális régiók atrófiáját okozza. Egyetlen folyamat önmagában nem azonosítható a kór kialakulása során, de számos molekuláris mechanizmust írtak le. A leginkább elfogadottak elméletek az Alzheimer - kór kialakulása kapcsán a következők:

1. A kolinerg teória (Francis 1999), amely azt fogalmazza meg, hogy a csökkent acetilkolin szintézis vezet a funkciózavarhoz. 
2. Szintén az Alzheimer kór kialakulását értelmezi a béta-amyloid teória (Gouras 2015) amely azt írja le, hogy az oldhatatlan amyloid béta prekurzor protein maradványok plakkokat képeznek, melyek károsítják a neuronokat.

3. Szintén a fehérjékhez kötődő elmélet az Alzheimer - kór kialakulása kapcsán a tau protein misfolding teória (Penke 2020), melynek leírása során kísérletesen igazolták, hogy a tau protein intracelluláris neurofibrilláris szálai tönkreteszik a mikrotubulusokat és károsítják a neuron transzport rendszerét.

\section{A vér-agy gát öregedésének szerepe az Alzheimer kór kialakulásában}

Az előzőekben felvázolt széles körben elfogadott teóriák mellett egyre inkább ismertté válik egy viszonylag új felfedezés, amely szerint a vér-agy gát öregedésének feltételezhetően alapvető szerepe van az idegrendszer öregedésében és az Alzheimer-kór kialakulásában is (Banks 2021).

A vér-agy gát nem egyszerüen a központi idegrendszer és a vér között speciális sejtek által alkotott határfelület, sokkal inkább egy specializált sejtekből álló rendszer melynek összetett funkciója van. A vér-agy gát meglétét már az 1800-s évek végén felismerte Paul Erlich, ugyanakkor müködésének teljes értelmezése napjainkban is folyik. Elsődleges szerepe az idegrendszer védelme, többek között a káros vegyületek agyszövetbe jutásának megakadályozásával. A vér agy-gát védelmi funkciója viszont nem csupán a káros anyagok bejutását gátolja meg, hanem a gyógyszerek agyba való bekerülését is, és ezzel megnehezíti a központi idegrendszeri betegségek kezelését. A vér-agy gát az immunrendszer elemeinek (például a test többi részében lévő makrofágok) agyba való bejutását sem teszi lehetővé (Erikson 2018). Az agy ezért saját védelmi rendszerrel rendelkezik, melynek fontos eleme az idegsejtek egyik speciális típusa a mikroglia, amely többek között folyamatosan ellenőrzi az agyi mikrokörnyezet állapotát. A mikroglia és a vér-agy gát túlsó oldalán működő immunrendszer között van kapcsolat, mely különféle jelzőanyagok egymásra hatásával valósul meg. A mikroglia a vér-agy gátra is hatással van az általa termelt citokinek, prosztaglandinok és egyéb vegyületek révén (Fonseca 2014). A vér-agy gát „fellazulásáról” egyes fertőzéseket követően már korábban publikáltak eredményeket (Lossonsky 2004). Kimutatták, hogy a vér-agy gát átjárhatóbbá válása mérhető az élő szervezetben a cereprospinalis folyadék (CSF) és a szérum albumin arányából, sőt ez az arányszám a vér-agy gát épségének az indikátoraként is használható (Erikson 2013). 
A legújabb eredmények azt mutatják, hogy az ApoE4 allélt hordozó betegeknél a véragy gát sokkal gyorsabban öregszik (Montagne 2020). Az APO fehérjék már korábban is ismertek voltak (Baird 2006), tudjuk, hogy az apolipoprotein E nevü fehérje az APOE génről termelödik, és a vérben keringő 5-féle fő apolipoprotein (A-E) egyike. A különböző apolipoproteinek kombinációja az APOE-genotípust adja meg. Az APOE-nek három

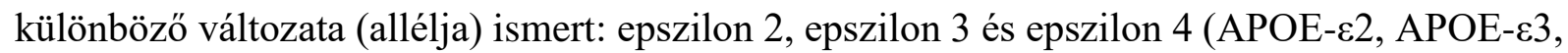
APOE- $\varepsilon 4)$. A leggyakrabban elöforduló változat az APOE- $\varepsilon 3$, amely a népesség $60 \%$-ában kimutatható.

Számos publikáció született, amelyek az APOE-ع4-nek a 65 év felett jelentkező, idős kori Alzheimer-kór kialakulásában játszott szerepét elemzik (Serrano-Poozo 2021). A kockázatnövelő hatás additív, vagyis ez a génváltozat egy példányban ( $22 / \varepsilon 4$ vagy $\varepsilon 3 / \varepsilon 4$ genotípus) valamennyire fokozza, két példányban ( $\varepsilon 4 / \varepsilon 4)$ erősebben fokozza az Alzheimer-kór esélyét. Fontos megjegyezni azonban, hogy ez a kockázat csak viszonylagos. Az APOE- 4 4pozitív emberek többsége soha nem lesz Alzheimer-kóros, és az Alzheimer-kórosok közül sokan APOE-ع4-negatívak. Az allotípusok vizsgálata alapján már külföldön és itthon is szogáltatásként végzik az ApoE4, mint Alzheimer -kór kockázati faktor vizsgálatát (e-cím 3).

A legújabb publikációkban a vér-agy gát öregedését és egyben átjárhatóbbá válását a periciták fokozott ütemü pusztulásával is jellemzik. Ugyanakkor egy éppen ellentétes folyamatot is megfigyeltek, melynek során az asztrociták hiperaktívvá válnak (Banks 2021).

Ez a felfedezés a molekuláris gerontológiai kutatások jelentős előremutató eredménye. Nem csupán az idegrendszer rendkívül komplex öregedési folyamatinak a jobb megértését teszi lehetővé, hanem a terápiás fejlesztésekhez is alapul szolgálhat. Egyrészt a vér-agy gát öregedése, "átjárhatóbbá válása" magyarázatot adhat arra is, miért reagálnak érzékenyebben az idősek bizonyos gyógyszerekre. Másrészt a fenti eredmények tükrében felmerül annak lehetősége, hogy a periciták funkcionalitását megőrző tevékenységek, például a rendszeres testmozgás, a kalóriabevitel visszafogása jótékony hatású lehet (amit egyébként a gyakorlat korábban igazolt is). A tapasztalati megfigyeléseken túl még perspektívikusabb az a felmerült lehetőség, hogy a periciták transzplantációjával lassítsák az idegrendszer öregedési folyamatát és az Alzheimer-kór elörehaladását (Tachibana 2018). 


\section{Összegzés}

Az öregedés komplex, molekuláris szintü folyamatainak megismerése és megértése napjainkban alapvető fontosságú. A molekuláris szintű mechanizmusok egyrészt értelmezik a klasszikus gerontológia élettani jelenségeit, másrészt prevenciós és terápiás lehetőségek alapját is képezhetik. Az idegrendszer öregedésével kapcsolatos új eredmények alátámasztják a fenti megállapítást, hiszen a vér-agy gát öregedésével kapcsolatban publikált és itt bemutatott eredmények egyaránt értelmezik a már ismert az öregedéssel társuló idegrendszeri változásokat, másrészt terápiás fejlesztések alapjául is szolgálhatnak.

\section{Irodalomjegyzék}

Baird, P.N., Richardson, A.J., Robman, L.D., Dimitrov, P.N., Tikellis, G, McCarty, C.A., \& Guymer, R.H. (2006) Apolipoprotein (APOE) gene is associated with progression of agerelated macular degeneration (AMD). Hum Mutat. 2006 Apr; 27 (4):337-42.

Banks, W., Reed, M., Logsdon, A., Rhea, E., \& Erickson, M. (2021): Healthy aging and the blood-brain barrier. Nature Aging volume 1, pages243-254 (2021)

Broccoli, D., Young, J.W., \& de Lange, T. (1995): Telomerase activity in normal and malignant hematopoietic cells. Proc Natl Acad Sci USA. 92: 9082-9086

Erickson, M., Banks, W., \& Danzer, R., (2018): Neuroimmune Axes of the Blood-Brain Barriers and Blood-Brain Interfaces: Bases for Physiological Regulation, Disease States, and Pharmacological Interventions. Pharmacological Reviews April 2018, 70 (2) 278-314

Erickson, M.A., \& Banks, W.A. (2013): Blood-brain barrier dysfunction as a cause and consequence of Alzheimer's disease. J Cereb Blood Flow Metab 33:1500-1513.

Fonseca AC, Matias D, Garcia C, Amaral R, Geraldo LH, Freitas C, \& Lima FR (2014): The impact of microglial activation on blood-brain barrier in brain diseases. Cell Neurosci 8:362. Gavrilov, L.A., \& Gavrilova, N.S. (2015): New Developments in the Biodemography of Aging and Longevity. Gerontology. 2015; 61(4):364-71.

Gouras, G.K., Olsson, T.T., \& Hansson, O. (2015): $\beta$-Amyloid peptides and amyloid plaques in Alzheimer's disease. Neurotherapeutics 2015 Jan. 12 (1):3-11.

Jones, D.P. (2015) Redox theory of aging. Redox Biol. 2015 Aug; 5 ():71-79. 
Kapahi P, Boulton ME, \& Kirkwood TB (1999) Positive correlation between mammalian life span and cellular resistance to stress. Free Radic Biol Med. 1999 Mar; 26 (5-6):495-500.

Kirkwood, T.B., Holliday, R., \& Rosenberger, R.F. (1984) Stability of the cellular translation process. Int Rev Cytol. 1984; 92():93-132.

Kvell, K., Pongrácz, J., Székely, M., Balaskó, M., Pétervári, E. \& Bakó, Gy. (2011): A Gerontológia Molekuláris és Klinikai Alapjai, Pécsi Tudományegyetem 2011. 51-129. o.

Lossinsky, A.S., \& Shivers, R.R. (2004): Structural pathways for macromolecular and cellular transport across the blood-brain barrier during inflammatory conditions. Histol Histopathol 19:535-564.

Park, S.H., Kang, H.J., Kim, H.S., Kim, M.J., Heo, J.I., Kim, J.H., Kho, Y.J., Kim, S.C., Kim, J., Park, J.B., \& Lee, J.Y. (2011) Higher DNA repair activity is related with longer replicative life span in mammalian embryonic fibroblast cells. Biogerontology. 2011 Dec; 12 (6):565-79.

Francis, P. T., Palmer, A. M., Snape, M., \& Wilcock, G. K. (1999). The cholinergic hypothesis of Alzheimer's disease: a review of progress. Journal of Neurology, Neurosurgery \& Psychiatry, 66(2), 137-147.

Penke, B., Szücs, M., \& Boglár, F. (2020): Oligomerization and Conformational Change Turn Monomeric $\beta$-Amyloid and Tau Proteins Toxic: Their Role in Alzheimer's Pathogenesis. Molecules. 2020 Apr; 25 (7): 1659

Rattan, S. I. (2007) The science of healthy aging: genes, milieu, and chance. Ann N Y Acad Sci. 2007 Oct; 1114 ():1-10.

Schmidt, M., \& Finley, D. (2013) Regulation of proteasome activity in health and disease. Biochim Biophys Acta. 2013

Semsei, I., (2011): Gerontológia, Debreceni Egyetemim kiadó 2011. 11-18. o., 49- 110.o.

Serrano-Pozo, A., Das, S., \& Hyman B. (2021): APOE and Alzheimer's disease: advances in genetics, pathophysiology, and therapeutic approaches. Lancet Neurol 2021 Jan; 20 (1):68-80 Slagboom P.E., Knook. D. L. (1990): Molecular Gerontology. Springer Nature. 1990. Pages $37-52$.

Rattan, S.I. (2018): Biogerontology: research status, challenges and opportunities, Acta Biomed. 2018; 89(2): 291-301. 
Tachibana, M,, Yamazaki, Y., Liu, C., Bu, G., \& Kanekiyo, T. (2018) Pericyte implantation in the brain enhances cerebral blood flow and reduces amyloid- $\beta$ pathology in amyloid model mice. Exp Neurol 2018 Feb; 300:13-21.

\section{Internetes hivatkozások}

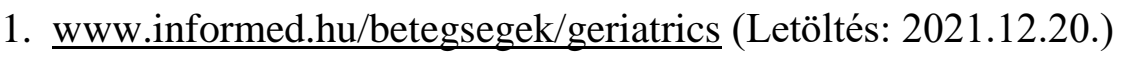

A gerontológia fogalma Geriátria - InforMed Orvosi és Életmód portál: gerontológia

2. https://www.ksh.hu/ (Letöltés: 2021.12.11.)

Magyarország népességének száma nemek és életkor szerint, 1870-2070 (ksh.hu)

3. https://www.nih.gov. (Letöltés: 2021.12.19.)

Study reveals how APOE4 gene may increase risk for dementia | National Institutes of Health $(\mathrm{NIH})$

\section{A Szerző:}

Pályiné dr. Krekk Zsuzsanna

ORCID : 0000-0002-2863-6313

adjunktus

Debreceni Egyetem Egészségügyi Kar Elméleti és Integratív Egészségtudományi Tanszék

Nyíregyháza Sóstói u. 2-4

Tel.: +36 52512900

E-mail cím: palyikrekk.zsuzsanna@foh.unideb.hu 